\title{
GENETIC DIVERSITY IN POPULATIONS OF Lupinus Elegans KUNTH, IMPLICATIONS FOR ECOLOGICAL RESTORATION
}

\section{DIVERSIDAD GENÉTICA DE POBLACIONES DE Lupinus Elegans KUNTH, IMPLICACIONES PARA RESTAURACIÓN ECOLÓGICA}

\author{
Sabina I. Lara-Cabrera ${ }^{1,3}$, Nancy Alejandre-Melena ${ }^{1}$, Edgar I. Medina-Sánchez ${ }^{\dagger}$ and \\ Roberto Lindig-Cisneros ${ }^{2}$
}

\begin{abstract}
${ }^{1}$ Laboratorio de Sistemática Molecular, Facultad de Biología, Universidad Michoacana de San Nicolás de Hidalgo. Ciudad Universitaria, Edificio R, PB. Francisco J. Mújica s/n. 58060, Morelia, Michoacán, México. ${ }^{2}$ Centro de Investigaciones en Ecosistemas. Universidad Nacional Autónoma de México (Campus Morelia). Antigua carretera a Pátzcuaro No. 8701. Ex. Hacienda de San José la Huerta. 58190, Morelia, Michoacán, México.
\end{abstract}

${ }^{3}$ Autor para correspondencia (slaracabrera@gmail.com)

\section{RESUMEN}

Lupinus elegans Kunth es una especie común de la región CentroOccidental de México. L. elegans se ha utilizado para la restauración de bosques de coníferas degradados porque crea un microambiente apropiado para el establecimiento de especies de coníferas al aumentar las concentraciones de nitrógeno del suelo. En este estudio se determinó la variación genética de poblaciones de $L$. elegans mediante marcadores moleculares RAPD. Se colectaron 150 individuos para cinco poblaciones de Michoacán: Llano de Pario, Charapan, Pico de Tancítaro, San Nicolás y Villa Madero. Los resultados indicaron una variación genética $(h)$ alrededor de 0.20 con $60 \%$ de polimorfismos. El análisis molecular mostró que la variación genética dentro de poblaciones $(59 \%)$ es mayor que entre poblaciones (41 \%). Con las distancias genéticas de Nei se generó un árbol "Neighbor Joining" que agrupa a las poblaciones de Llano de Pario y de San Nicolás, seguidas de las de Tancítaro, y finalmente agruparon las de Villa Madero y Charapan. No se encontró correlación entre las distancias genéticas y geográficas. Plantas provenientes de la población local se desarrollaron mejor que las introducidas en los experimentos de jardín común. Estos resultados sugieren que a pesar del amplio rango de distribución de $L$. elegans, la colecta de semillas para proyectos de restauración se debe realizar lo más cerca (geográficamente) a la población local posible.

Palabras clave: Lupinus elegans, diversidad genética, población, restauración ecológica.

\section{SUMMARY}

Lupinus elegans Kunth is a common species in the West-Central region of México. L. elegans has been used for the restoration of degraded conifer forests because it creates microenvironments suitable for the establishment of coniferous species by increasing nitrogen concentrations in the soil. In this study we determined the genetic variation of $L$. elegans populations using RAPD markers. One hundred and fifty individuals were collected from five populations in Michoacán: Llano de Pario, Charapan, Pico de Tancítaro, San Nicolás and Villa Madero. Results indicate genetic variation (h) about 0.20 with $60 \%$ polymorphism. The molecular analysis showed higher genetic variation within (59 \%) than between (41 \%) populations. A Neighbor Joining tree was generated based on Nei's genetic distances, and the resulting tree clustered the populations of Llano de Pario and San Nicolás, followed by populations of Tancítaro, and lastly clustered Villa Madero and Charapan. No correlation was found between genetic and geographic distances. Common garden experiments indicate that plants from the local population outperform introduced plants. These results suggest that although $L$. elegans is a species with a considerable geographic range, seed collection for restoration purposes should be done from the closest (geographical) population possible.

Index words: Lupinus elegans, genetic diversity, population, ecological restoration.

\section{INTRODUCTION}

Lupinus is a nitrogen fixating genus with about 200 species distributed in the Mediterranean region, Africa and America (McVaugh, 1987). Some species such as Lupinus albus L. and Lupinus elegans Kunth have been used for ecological restoration (Blanco-García and Lindig-Cisneros, 2005; Burton et al., 2006). L. elegans, an outcrosser is a long-lived perennial shrub (Ainouche and Bayer, 1999). It is endemic to Mexico, distributed from 1800 to 3000 masl, in pine and pine-oak forests in the states of Guerrero, Jalisco, Michoacán, Morelos and Zacatecas (Dunn, 2001). L. elegans is a highly plastic species characteristic of early successional stages. Germination requirements are well known (Medina-Sánchez and Lindig-Cisneros, 2005), and propagation techniques have also been developed (Alvarado-Sosa et al., 2007). This species inhabits seven different types of plant communities in the Meseta Purépecha region in Michoacán, having the largest distribution then any other legume species in the region (Medina et al., 2000). The species has been used for 
restoring areas affected by volcanism (Blanco-García and Lindig-Cisneros, 2005) and is currently used in the restoration of heavily degraded agricultural lands.

The field of restoration genetics is concerned with the genetic performance of introduced species (Hufford and Mazer, 2003) and, among other things, focuses on delineating seed collecting zones. Restoration ecology projects introduce native species into degraded sites. Hufford and Mazer (2003) and Galloway and Fenster (2000) call for studies on genetic diversity of the source populations used for reintroduction, along with evidence from common garden experiments, to ensure appropriate plant performance in restoration projects, thus avoiding under or outperformance of the new phenotypes in local populations (Gustafson et al., 2005; McKay et al., 2005). Studies on the genetic diversity of restored populations are also needed (Liu et al., 2008).

RAPD markers have been used for many years to assess genetic diversity in populations because this technique provides a quick and reliable tool (Williams et al., 1990). RAPD have been widely used for genetic diversity studies within the legumes, for example: Crotalaria longipes Raf. (Jayanthi and Mandal, 2001), Dalea purpurea Vent. (Gustafson et al., 2002), Desmodium sumichrastii (Schinder) Standley (BedollaGarcía and Lara-Cabrera, 2006) and Vicia pisiformis L.(Black- Samuelsson et al., 1997; Black-Samuelsson and Lascoux, 1999). Talhinhas et al. (2003) tested the reliability of molecular markers to assess inter-species genetic diversity among lupin species and obtained similar results when using AFLPs, ISSRs and RAPDs. No genetic diversity studies using RAPD markers have been reported for lupin; there are no reports either of studies undertaken to assess genetic diversity of lupin species for ecological restoration purposes.

The present study was undertaken to assess the genetic diversity of natural populations of Lupinus elegans, to determine how genetic variation is distributed among and within populations from different regions in order to aid in the decision-making process for determining seed collection ranges, and finally to perform common garden experiments under restoration conditions with seeds collected from the same natural populations.

\section{MATERIALS AND METHODS}

\section{Plant material and RAPD amplification}

Thirty individuals from five populations of Lupinus elegans were collected in Michoacán (Table 1), and all samples were made at random avoiding close neighbors when possible. The collection sites were: San Nicolás (where the restoration site is located), Llano de Pario (the population nearest San Nicolás), and Tancítaro and Charapan within 450 to $500 \mathrm{kms}$ from San Nicolás, and the farthest Villa Madero at $670 \mathrm{kms}$. From the five populations, those from Tancítaro and Villa Madero were present in well preserved pine-oak forests. San Nicolás plants were found in abandoned agricultural fields near forest edges. Llano de Pario and Charapan plants were found in the most degraded areas. The Llano de Pario population was in an area affected by volcanic ash deposition from the Paricutín volcano which erupted more than 50 years ago and recently by cattle grazing. Charapan is a secondary pine-oak forest severely overgrazed and next to a state highway.

Young and healthy leaves were randomly collected in the five populations for a total of 150 individuals (Table 1). Voucher specimens were deposited at MEXU and IEB. DNA extraction was performed following Lefort and Douglas (1999). DNA concentration was determined using a Spectrophotometer (Jenway Designed model 6305) at 260/280 wavelength. Each polymerase chain reaction (PCR) included $0.05 \mu \mathrm{g} \mu \mathrm{L}^{-1}$ of DNA.

Thirty decamer primers (Series OPA, OPB, OPC, OPD, OPF, OPH and OPR from Operon Technologies, Alameda, California, U.S.A.) were screened and of these, ten primers in five of the series (Table 2) exhibited high polymorphism and repeatability. In most instances, DNA from each plant was amplified with the same primer more than once and the banding patterns compared. Final volume for PCR reaction was $25 \mu \mathrm{L}:$ : $15.5 \mu \mathrm{L}$ of water, $1 \mu \mathrm{L} \mathrm{MgCl} 2(50 \mathrm{mM}), 1.5 \mu \mathrm{L}$ of oligonucleotides $(10 \mathrm{~nm})$, $1 \mu \mathrm{L}$ BSA (10mg $\left.\mu \mathrm{L}^{-1}\right), 2.5 \mu \mathrm{L}$ of 10X PCR Buffer, $2 \mu \mathrm{L}$ (10mM) dNTP's (dATP, dCTP, dGTP, dTTP), $0.5 \mu \mathrm{L}$ of recombinant Taq DNA polymerase (Invitrogen, San Diego, California, U.S.A.) and $1 \mu \mathrm{L}\left(0.05 \mu \mathrm{g} \mu \mathrm{L}^{-1}\right)$ of DNA. The thermal cycle program was run on a Techne TC-412 thermal cycler. The program consisted of 44 cycles, each at $94{ }^{\circ} \mathrm{C}$ for $1 \mathrm{~min}, 36{ }^{\circ} \mathrm{C}$ for $1 \mathrm{~min}, 72{ }^{\circ} \mathrm{C}$ for $2 \mathrm{~min}$ and final extension at $72{ }^{\circ} \mathrm{C}$ for $7 \mathrm{~min}$.

Amplification products were electrophoresed in $1.5 \%$ agarose gels with $0.5 \mathrm{X}$ TBE buffer $(0.045 \mathrm{M}$ Trizma base, $0.045 \mathrm{M}$ boric acid and $0.001 \mathrm{M}$ EDTA) at $120 \mathrm{~V}$ for $3 \mathrm{~h}$ and stained with ethidium bromide $\left(0.1 \mu \mathrm{g} \mathrm{mL}^{-1}\right)$. Gels with amplification fragments were visualized and photographed under UV light in a Transilluminator UVPBioDoc-It ${ }^{\mathrm{TM}}$ System (Bioimaging system). Molecular mass of the RAPD bands was estimated by comparison to a 123bp ladder (Invitrogen, San Diego, California, U.S.A.). 
Table 1. Sampled populations of Lupinus elegans with geographical location, voucher specimen (collectors name and number), number of individuals per population, altitude and vegetation type.

\begin{tabular}{|c|c|c|c|c|c|}
\hline Locality & Voucher specimen & GPS coordinates & Population size & $\begin{array}{c}\text { Altitude } \\
(\mathrm{m})\end{array}$ & Vegetation \\
\hline San Nicolás & Alejandre-Melena 260 & $\begin{array}{r}19^{\circ} 24^{\prime} 60^{\prime \prime} \mathrm{N} \\
102^{\circ} 14^{\prime} 46^{\prime \prime} \mathrm{W}\end{array}$ & $>500$ & 2850 & $\begin{array}{l}\text { Agricultural land } \\
\text { with POF }\end{array}$ \\
\hline Llano de Pario & Alejandre-Melena 261 & $\begin{array}{l}19^{\circ} 29^{\prime} 6^{\prime \prime} \mathrm{N} \\
102^{\circ} 11^{\prime} 46^{\prime \prime} \mathrm{W}\end{array}$ & 237 & 2470 & PF, Ash \\
\hline Tancítaro & Alejandre-Melena 259 & $\begin{array}{c}19^{\circ} 22^{\prime}, 13 " \mathrm{~N} \\
102^{\circ} 20^{\prime} 24^{\prime \prime} \mathrm{W}\end{array}$ & $>500$ & 2343 & POF, PF \\
\hline Charapan & Alejandre-Melena 265 & $\begin{array}{c}19^{\circ} 34^{\prime} 4^{\prime \prime} \mathrm{N} \\
102^{\circ} 14^{\prime} 51 \text { " W }\end{array}$ & 124 & 2399 & Secondary POF \\
\hline Villa Madero & Alejandre-Melena 264 & $\begin{array}{c}19^{\circ} 18^{\prime} 59 " \mathrm{~N} \\
101^{\circ} 21^{\prime} 52^{\prime \prime} \mathrm{W}\end{array}$ & 48 & 2183 & POF \\
\hline
\end{tabular}

POF $=$ Pine-Oak forest; $\mathrm{PF}=$ Pine forest.

Table 2. Oligonucleotides employed and RAPD markers obtained for the 150 individuals examined.

\begin{tabular}{|c|c|c|c|c|}
\hline Oligonucleotide & Sequence $\left(5^{\prime}-3^{\prime}\right)$ & No. of monomorphic bands & No. of polymorphic bands & $\begin{array}{l}\text { Total no. of } \\
\text { bands }\end{array}$ \\
\hline OPA-01 & CAGGCCCTTC & 0 & 9 & 9 \\
\hline OPA-02 & TGCCGAGCTG & 0 & 14 & 14 \\
\hline OPB-11 & GTAGACCCGT & 0 & 20 & 20 \\
\hline OPB-17 & AGGGAACGAG & 0 & 18 & 18 \\
\hline OPC-02 & GTGAGGCGTC & 0 & 16 & 16 \\
\hline OPD-20 & ACCCGGTCAC & 1 & 10 & 11 \\
\hline OPF-01 & ACGGATCCTG & 0 & 13 & 13 \\
\hline OPH-03 & AGACGTCCAC & 0 & 17 & 17 \\
\hline OPH-13 & GACGCCACAC & 0 & 16 & 16 \\
\hline OPH-15 & AATGGCGCAG & 2 & 6 & 8 \\
\hline Total & & 3 & 139 & 142 \\
\hline
\end{tabular}

\section{RAPD data analysis}

Amplified products were scored as the presence (1) or absence (0) of homologous bands; because RAPDs are dominant markers (Williams et al., 1990) we assumed that each band represented a single band locus. Only those fragments amplifying strongly in each instance were included in the analyses. Based on these data, we calculated the percentage of polymorphism (\%P) and Shannon's diversity index (Ho, Observed heterozygosity)
(Nei, 1973) assuming that populations are not under Hardy-Weinberg equilibrium, using the program POPGEN ver. 1.31 (Yeh and Yang, 1999).

Analysis of molecular variance (AMOVA) was used to calculate the partitioning of genetic variation between and within populations. The significance of the different variance components was estimated from distributions generated from $10 \quad 000$ random permutations in ARLEQUIN ver. 3.01 (Excoffier et al., 2006). 
A genetic distance and identity matrix was calculated using Nei's genetic distance. A Neighbor Joining (Saitou and Nei, 1987) dendrogram based on pairwise measures of genetic distance was generated in PAST v. 1.55 (Hammer et al., 2001). The reliability of the Neighbor Joining dendrogram was tested by bootstrap analysis with 1000 replications.

The normalized Mantel statistic ( $\mathrm{r}_{\mathrm{M}}$ ) (Mantel, 1967) was calculated between the genetic and the geographic distance matrices in the program Tools for Population Genetic Analyses (TFPGA) v. 1.3 (Millar, 1997). The significance of $\mathrm{rm}$ was tested by a permutation test $(10000$ iterations) to determine if there is a relationship between the genetic composition and the geographic distribution of the populations.

\section{Common garden experiments}

A reciprocal transplant study was attempted at two restoration sites adjacent to the populations of San Nicolas and Llano de Pario. Nevertheless, all plants died at Llano de Pario before the experiment started; only the experiment at San Nicolás is described. One hundred and twenty seeds, in groups of two, were sown from each population following the design of a Latin square lattice with a distance of $40 \mathrm{~cm}$ between planting points. When both seeds within the same planting point germinated, the second seedling was eliminated in order to have 60 plants from each population. The experiment was set up during the first week of June, 2005 and followed every month for a complete growing season, until December of the same year. The number of plants present at the end of the growing season and the height for each plant were recorded. Plants from the Llano de Pario population were eliminated from the San Nicolás site at the end of the growing season to prevent cross pollination the following year.

A common garden experiment was set up at the University grounds located in the City of Morelia $\left(19^{\circ} 41^{\prime} \mathrm{W}, 101^{\circ} 12^{\prime} \mathrm{N}, 1921 \mathrm{masl}\right)$ using five tubs of 210 Leach. Seeds were collected from four populations: San Nicolás, Llano de Pario, Charapan and Tancítaro. These produced enough seeds the same year that leaf samples for genetic analyses were collected. In each tub, eight plants from each population were grown for a total of 40 plants per population. The experiment was set up during the first week of June 2005 and followed for a complete growing season, until December of the same year. The number of plants present at the end of the growing season and the height for each plant were recorded.
Establishment was analyzed using Chi squared tests or analyses of deviance on generalized linear models (GLM) for binomial distributed data considering each plant as an experimental unit (Dobson, 2002). ANOVA was applied to test differences in height among populations. Residuals were checked for compliance with ANOVA assumptions. For the common garden experiment, missing height data resulting from nine dead plants were replaced with the mean for the treatment; each tub was considered a block for the statistical analysis. Data shown are means and standard errors of the mean. All analyses were carried out using the statistical software $\mathrm{R}$ ( $\mathrm{R}$ Development Core Team 2008).

\section{RESULTS AND DISCUSSION}

\section{Genetic Diversity}

Of 142 amplified bands (a sample is shown in Figure 1) $96 \%$ were polymorphic (Table 3 ). The percentage of polymorphic bands ranged from 49 to $56 \%$, with the highest percentages in San Nicolás and Tancítaro (56 and $54 \%$ respectively), and the lowest in Charapan (49 \%). Sampled populations differed in genetic diversity as shown by Shannon's diversity index (Table 3), the highest genetic diversity (I) of 0.2144 for Tancítaro and Villa Madero, followed by San Nicolás, Llano de Pario and Charapan. These values are similar to that of Dalea purpurea (0.21), another widely distributed legume (Gustafson et al., 2002).

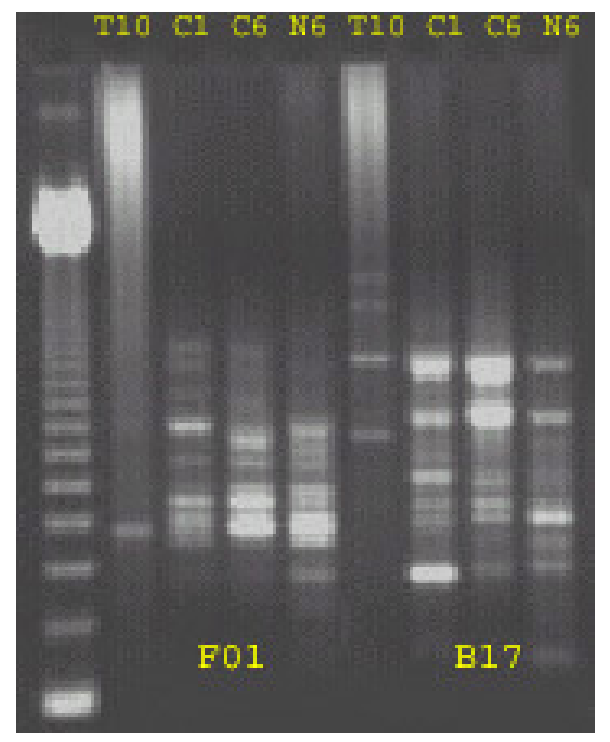

Figure 1. An example of polymorphisms found with amplification of two oligonucleotides F01 and B17 for individuals of Lupinus elegans. The first lane shows the 123bp DNA ladder. The same four individuals were included for each oligonucleotide, the codes indicate the population $(\mathrm{T}=$ Tancítaro, $\mathrm{C}=$ Charapan and $\mathrm{N}=$ San Nicolás), and the number refers to the particular individual. 
Table 3. Genetic variation within populations of Lupinus elegans based on RAPD data.

\begin{tabular}{|c|c|c|c|c|c|c|}
\hline Population & $\begin{array}{l}\text { Number of alleles } \\
\text { per locus (No) }\end{array}$ & $\begin{array}{l}\text { Effective number of } \\
\text { alleles per locus (Ne) }\end{array}$ & $\begin{array}{l}\text { Nei's genetic } \\
\text { distance (h) }\end{array}$ & $\begin{array}{l}\text { Shannon Index } \\
\text { (I) }\end{array}$ & $\begin{array}{c}\text { Number of } \\
\text { polymorphic loci }\end{array}$ & $\begin{array}{c}\text { Percentage of } \\
\text { polymorphic loci }(\%)\end{array}$ \\
\hline Llano de Pario & 1.5070 & 1.1961 & 0.1210 & 0.1922 & 72 & 50.70 \\
\hline San Nicolás & 1.5634 & 1.2115 & 0.1335 & 0.2131 & 80 & 56.34 \\
\hline Tancítaro & 1.5423 & 1.2245 & 0.1368 & 0.2144 & 77 & 54.23 \\
\hline Villa Madero & 1.5211 & 1.2147 & 0.1360 & 0.2144 & 74 & 52.11 \\
\hline Charapan & 1.4859 & 1.1907 & 0.1203 & 0.1905 & 69 & 48.59 \\
\hline $\begin{array}{l}\text { Among } \\
\text { populations }\end{array}$ & 1.9577 & 1.2928 & 0.1884 & 0.3078 & 136 & 95.77 \\
\hline
\end{tabular}

Total genetic diversity for all populations (Hsp) was 0.1884 . From these values the proportion of total genetic variation among populations (Hpop/Hsp) was 0.6873 . The proportion of genetic diversity shared between populations as calculated by Gsт $=0.3128$ (Nei, 1973) indicated that ca. $30 \%$ of genetic diversity occurred among populations. Gst values are similar to those found in other legume species: Desmodium sumichrastii $\left(\mathrm{Gst}_{\mathrm{st}}=0.3271\right)$ (BedollaGarcía and Lara-Cabrera, 2006) and Medicago truncatula $\left(\right.$ Fst $_{\text {s }}$ 0.32) (Bonnin et al., 2001). Higher population structure scores have been found for outcrossing crop species (Hamrick and Godt, 1997). The estimate of gene flow between the populations in one generation $(\mathrm{Nm})$ was 1.1 (one individual per generation) which would suffice to overcome the homogenizing effects of genetic drift (Ellstrand and Ellam, 1993).

Genetic distance and genetic identity (Table 4) indicated that the populations showing the greatest similarity were Villa Madero and Tancítaro and those differing the most were Charapan and Llano de Pario. The partitioning of genetic diversity as revealed by AMOVA (Table 5) showed the larger fraction of variation (\%\$-st, percentage of the overall differentiation among populations) was within populations (59.2\%, P $<0.00001)$, compared to a 40.7 $\%(\mathrm{P}<0.00001)$ variation among populations; in accordance with large cross pollinated species (Agrimonti et al., 2007; Huff et al., 1993; Nebauer et al., 1999; Yu and Pauls, 1993). Similar results have been found in Desmodium sumichrastii with $61 \%$ within population variation reported (Bedolla-García and Lara-Cabrera, 2006), and higher within population variation for Trifolium pratense with $76 \%$ variation (Campos de Quiroz and Ortega-Klose, 2001).

RAPD evidence for L. elegans showed no correlation between genetic and geographic distances following the Mantel correlation test $(\mathrm{P}=0.619)$ for these populations. The Neighbor Joining tree (Figure 2) for all populations based on Nei's genetic distances, showed two clusters with $100 \%$ of bootstrap confidence splitting Llano de Pario and
San Nicolás (69\% of bootstrap support), and Tancítaro (>50\% of bootstrap support) from Villa Madero and Charapan (70\% of bootstrap support).

\section{Common garden experiments}

The reciprocal transplant study at the restoration site near the population of San Nicolás showed that plants from local stock had a significantly higher survival rate, and were nearly $20 \%$ taller than plants from Llano de Pario, despite the fact that these populations are more closely related genetically. Survival differed between populations: $30 \%$ of the plants from the Llano de Pario population survived and $60 \%$ of the plants from San Nicolás, the local population, survived. Differences were statistically significant $\left(X^{2}=9.73 ; P=0.002\right)$. Plant eight at the end of the growing season also varied between populations, with plants from San Nicolás $(110 \pm 7 \mathrm{~cm})$ being taller than plants from Llano de Pario $(90 \pm 7 \mathrm{~cm})$. The difference in height between populations was $18 \%$, but only marginally significant $\left(\mathrm{F}_{(1,52)}=2.9 ; P=0.09\right)$.

The common garden experiment showed that if conditions are less demanding no differences in survival occur (only nine plants from different populations died), but populations still differ in growth (Figure 3 ). The tallest plants were those from the Llano de Pario population (66 $\pm 2 \mathrm{~cm})$ and Tancítaro $(66 \pm 2 \mathrm{~cm})$, followed by plants from Charapan $(62 \pm 2 \mathrm{~cm})$ and finally plants from San Nicolás $(55 \pm 2 \mathrm{~cm})$, the differences being statistically significant (Table 6).

These differences in performance in the common garden experiment can be explained by the geographic origin of the plants. San Nicolás, growing at the highest altitude, is located at 2850 masl and the common garden experiment was set-up at 1950 masl, a difference of 900 $\mathrm{m}$. The other populations differed in altitude from 393 to $520 \mathrm{~m}$ from the altitude of the site of the common garden experiment. Differences in performance across altitudinal gradients have been found for other forest species in the region, puch as Pinus oocarpa and $P$. pseudostrobus (Viveros-Viveros et al., 2005; Sáenz-Romero et al., 2006). 


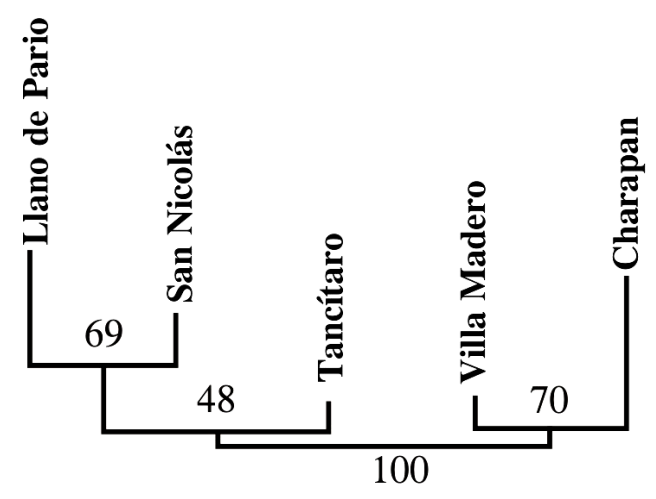

Figure 2. Neighbor joining dendrogram based on pairwise measures of Nei's genetic distances. Numbers on branches represent bootstrap confidence values for 1000 replicates.

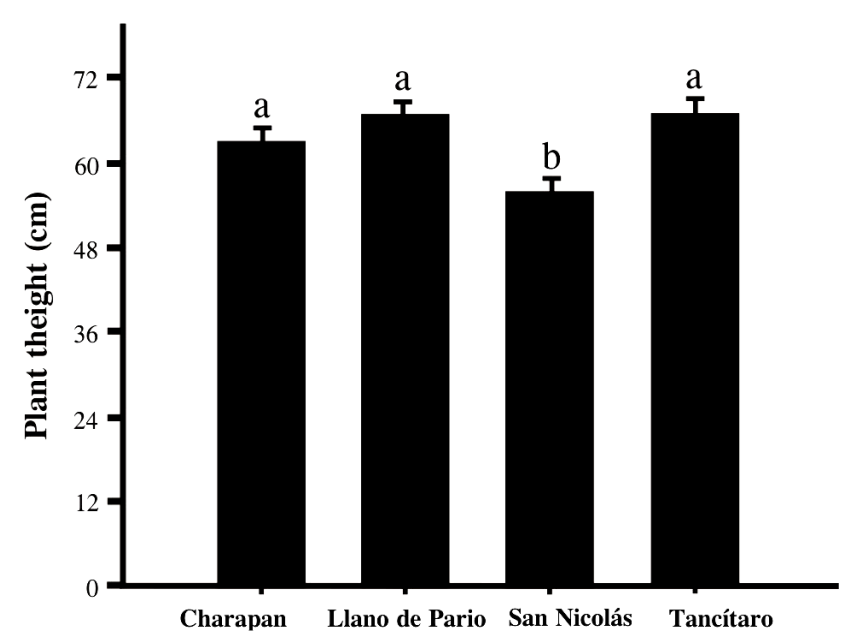

Figure 3. Heights of Lupinus elegans plants at the end of the common garden experiment. Different letters represent significant differences among populations according to Tukey test (data are means and standard errors of the means).

Table 4. Genetic distance (GD) among populations: Nei's genetic identity (GI) above diagonal and genetic distance below diagonal.

\begin{tabular}{lccccc}
\hline Population & Llano de Pario & San Nicolás & Tancítaro & Villa Madero & Charapan \\
\hline Llano de Pario & - & 0.9128 & 0.9155 & 0.9189 & $\mathbf{0 . 8 8 8 0}$ \\
San Nicolás & 0.0912 & - & 0.9226 & 0.9114 & 0.9061 \\
Tancítaro & 0.0883 & 0.0806 & - & $\mathbf{0 . 9 4 8 1}$ & - \\
Villa Madero & 0.0846 & 0.0927 & $\mathbf{0 . 0 5 3 3}$ & 0.9119 \\
Charapan & $\mathbf{0 . 1 1 8 7}$ & 0.0986 & 0.0922 & 0.0844 & - \\
\hline
\end{tabular}

Table 5. Analysis of molecular variance (AMOVA).

\begin{tabular}{lccccc}
\hline Source of variation & $\mathrm{df}$ & Sum of squares (SSD) & $\begin{array}{c}\text { Variance component } \\
\text { estimates (CV) }\end{array}$ & $\begin{array}{c}\text { Percentage of } \\
\text { variation (PV) }\end{array}$ & $\begin{array}{c}\text { Probability of significance } \\
\text { (PS) }\end{array}$ \\
\hline Among populations & 4 & 944.4 & 7.5 & 40.7 & $<0.00001$ \\
Within populations & 144 & 1581.1 & 10.9 & 59.2 & $<0.00001$ \\
Total & 148 & 2525.5 & 18.5 & & \\
\hline $\mathrm{df}=$ degrees of freedom. & & & &
\end{tabular}

Table 6. ANOVA table for heights of Lupinus elegans plants at the end of the common garden experiment.

\begin{tabular}{lrcccc}
\hline & df & Sum of squares & Mean squares & F & $P$ \\
\cline { 2 - 6 } Block & 4 & 2917 & 729 & 5.25 & $<0.0001$ \\
Population & 3 & 3322 & 1107 & 9.97 & $<0.00001$ \\
Block:Population & 12 & 2982 & 248 & 1.79 & 0.06 \\
Residuals & 140 & 19457 & 139 & & \\
\hline
\end{tabular}

These results have direct consequences for restoration practice because although $L$. elegans is a species with a considerable geographic range, seed collecting for restoration purposes should be done from the closest population possible. Genetic evidence reported here and our trial at San Nicolás indicates that populations as close as $10 \mathrm{~km}$ perform differentially. This range is considerably lower than the range recommended for seed collection for Mexican temperate tree species (Vargas et al., 2004) although it is similar to the range recommended for some native prairie species in North America (Gustafson et al., 2005).

\section{CONCLUSIONS}

Populations of Lupinus elegans for the West-Central part of Mexico are highly variable both within and among populations when using RAPD's. The Neighbor Joining tree clustered together the populations of Llano de Pario and San Nicolás, followed by populations of Tancítaro and lastly clustered Villa Madero and Charapan. Nevertheless 
no correlation was found between genetic and geographic distances. Common garden experiments indicate that plants from the local population outperform introduced plants. The reciprocal transplant study showed that plants from local stock (San Nicolás) performed better than plants from the other population tested (Llano de Pario), a similar trend of significant differences in growth was observed in the common garden experiment, suggesting that populations might be highly adapted to local conditions.

\section{ACKNOWLEDGEMENTS}

We are indebted to Dr. Ken Oyama and M. Sc. Nidia Perez-Nasser for critical support for developing laboratory work. We gratefully acknowledge suggestions from Dr. Alfonso Delgado, Dr. Cuauhtémoc Sáenz-Romero, M. Sc. Norma Oropeza, and critical review of the manuscript by Sara Stephenson, Dr. Yvonne Herrerías-Diego. Funding for this research was obtained through the following grants to RLC and SILC: CONACYT-SEMARNAT-C01-0760 and Coordinación de la Investigación Científica from UMSNH project 8.16.

\section{BIBLIOGRAPHY}

Agrimonti C, R Bianchi, A Bianchi, M Ballero, F Poli, N Marmiroli (2007) Understanding biological conservation strategies: a molecular genetic approach to the case of Myrtle (Myrtus communis L.) in two Italian regions: Sardinnia and Calabria. Conserv. Genet. 8:385-396.

Ainouche A K, R J Bayer (1999) Phylogenetic relationships in Lupinus (Fabaceae : Papilionoideae) based on internal transcribed spacer sequences (ITS) of nuclear ribosomal DNA. Am. J. Bot. 86:590607.

Alvarado-Sosa P, A Blanco-García, R Lindig-Cisneros (2007) Test of alternative nursery propagation conditions for Lupinus elegans Kunth plants, and effects on field survival. Rev. Fitotec. Mex. 30:201-204.

Bedolla-García B, S Lara-Cabrera (2006) An assesment of genetic diversity in Desmodium sumichrastti (Fabaceae) for Central Mexico. Can. J. Bot. 84:876-882.

Black-Samuelsson S, G Eriksson, L Gustafsson, P Gustafsson (1997) RAPD and morphological analysis of the rare plant species Vicia pisiformis (Fabaceae). Biol. J. Linn. Soc. 61:325-343.

Black-Samuelsson S, M Lascoux (1999) Low isozyme diversity in Nordic and central European populations of Vicia pisiformis and V. dumetorum (Fabaceae). Nord. J. Bot. 19:643-652.

Blanco-García A, R Lindig-Cisneros (2005) Incorporating restoration in sustainable forestry management: Using pine bark mulch to improve native-species establishment on tephra deposits. Rest. Ecol. 13:703-709.

Bonnin I, J Ronfort, F Wozniak, I Oliveri (2001) Spatial effects and rare outcrossing events in Medicago truncatula (Fabaceae). Mol. Ecol. 10:1731-138.3

Burton CM, P J Burton, R Hebda, N J Turner (2006) Determining the optimal sowing density for a mixture of native plants used to revegetate degraded ecosystems. Rest. Ecol. 14:379-390.

Campos-de-Quiroz H, F Ortega-Klose (2001) Genetic variability among elite red clover (Trifolium pratense L.) parents used in Chile as revealed by RAPD markers. Euphytica 122:61-67.

Dobson A J (2002) An introduction to generalized linear models. $2^{\text {nd }} e d$.
Chapman and Hall-CRC. Boca Raton, Florida. U.S.A. pp: 111130.

Dunn D B (2001) Lupinus. In: Flora Fanerogámica del Valle de México. G. R. Calderón de R., J. Rzedowski (eds) Instituto de Ecología, A. C., CONABIO. Pátzcuaro, Michoacán. México. pp:290-300.

Ellstrand N C, D R Elam (1993) Population genetic consequences of small population size: implication for plant conservation. Ann. Rev. Ecol. Syst. 24:217-242.

Excoffier L, G Laval, S Schneider (2006) Arlequin ver 3.01. An Integrated Software Package for Population Genetics Data Analysis. Switzerland.

Galloway F L, C B Fenster (2000) Population differentiation in an annual legume: local adaptation. Evolution 54:1173-1181.

Gustafson D J, D J Gibson, D L Nickrent (2002) Genetic diversity and competitive abilities of Dalea purpurea (Fabaceae) from remnant and restored grassland. Int. J. Plant Sci. 163:979-990.

Gustafson D J, D J Gibson, D L Nickrent (2005) Using local seeds in prairie restoration data support the paradigm. Native Plants $\mathbf{J}$. 6:25-28.

Hammer O, D A T Harper, P D Ryan (2001) PAST: Paleontological statistics software package for education and data analysis. Paleontol. Electron. 4:1-9.

Hamrick J L, M J W Godt (1997) Allozyme diversity in cultivated crops. Crop Sci. 37:26-30.

Huff D, R Peakall, P Smouse (1993) RADP variation within and among natural populations of outcrossing buffalograss (Buchloe dactyloides (Nutt.) Engelm. Theor. Appl. Genet. 86:927-934.

Hufford KM, S J Mazer (2003) Plant ecotypes: genetic differentiation in the age of ecological restoration. Trends Ecol. Evol. 18:147-155.

Jayanthi M, K P Mandal (2001) Low genetic polymorphism in natural populations of Crotalaria longipes. Biol. Plant. 44:455-457.

Lefort F, C G Douglas (1999) An efficient micro-method of DNA isolation from mature leaves of four hardwood tree species Acer, Fraxinus, Prunus and Quercus. Ann. For. Sci. 56:259-263.

Liu M, X Chen, $X$ Zhang, D Shen (2008) A population genetic evaluation of ecological restoration with the case study on Cyclobalanopsis myrsinaefolia. Plant Ecol. 197:31-419.

Mantel N A (1967) The detection of disease clustering and a generalized regression approach. Cancer Res. 27:209-220.

McKay K J, C E Christian, S Harrison, K J Rice (2005) "How local is local" -A review of practical and conceptual issues in the genetics of restoration. Rest. Ecol. 13:432-440.

McVaugh R (1987) Flora Novo-Galiciana: A descriptive account of the vascular plants of western México. The University of Michigan Press. USA. 5:580-598.

Medina C, F Guevara, M A Martínez, P Silva-Sáenz, A ChávezCarvajal, M García (2000) Estudio florístico en el área de la comunidad indígena de Nuevo San Juan Parangaricutiro, Michoacán, México. Instituto de Ecología, A. C. Acta Bot. Mex. 52:5-41.

Medina-Sánchez E, R Lindig-Cisneros (2005) Effect of scarification and growing media on seed germination of Lupinus elegans H. B. K. Seed Sci. Technol. 33:237-241.

Millar M P (1997) Tools for population genetic analyses (TFPGA) $1.3 \mathrm{~A}$ Windows program for the analysis of allozyme and molecular population genetic data. Computer software distributed by author.

Nebauer S G, L del Castillo-Agudo, J Segura (1999) RAPD variation within and among natural populations of outcrossing willowleaved foxglove (Digitalis obscura L.) Theor. Appl. Genet. 98:985-994.

Nei M (1973) Analysis of gene diversity in subdivided populations. P. Natl. Acad. Sci. USA 70:3321-3323.

R Development Core Team (2008) R: A Language and Environment for Statistical Computing. Viena, Austria. URL http://www.Rproject.com.

Sáenz-Romero C， R R Guzman-Reyna, G E Rehfeldt (2006) Altitudinal genetic variation among Pinus oocarpa populations in 
Michoacan, Mexico - Implications for seed zoning, conservation, tree breeding and global warming. For. Ecol. Manage. 229:340350 .

Saitou N, M Nei (1987) The neighbor-joining method: a new method for reconstruction of phylogenetic trees. Mol. Biol. Evol. 4:406-425.

Talhinhas P, J N Martins, J Leitáo (2003) AFLP, ISSR and RAPD markers reveal high levels of genetic diversity among Lupinus spp. Blackwell Verlag, Berlin. Plant Breed. 122:507-510.

Vargas J J, B Bermejo, F T Ledig (2004) Manejo de Recursos Genéticos Forestales. Comisión Nacional Forestal. Secretaría de Medio Ambiente y Recursos Naturales. México. pp:46-78.

Viveros-Viveros H, C Sáenz-Romero, J López-Upton, J J VargasHernández (2005) Altitudinal genetic variation in plant growth of
Pinus pseudostrobus Lindl. in field testing. Agrociencia 39:575587.

Williams J G K, A R Kubelik, K J Livak, J A Rafalski, S Tingey (1990) DNA polymorphism amplified by arbitrary primers are useful as genetic markers. Nucleic Acids Res. 18:5531-6535.

Yeh C F, R Yang (1999) Popgene version 1.3.1. Microsoft windowbased freeware for population genetic analysis. University of Alberta and Tim Boyle. Centre for International Forestry Research. Canada.

Yu K, K P Pauls (1993) Rapid estimation of genetic relatedness among heterogeneous populations of alfalfa by random amplification of bulked genomic DNA samples. Theor. Appl. Genet. 86:788-794. 